\title{
Analyzing Students' Needs on Reading Text Material at Vocational High School
}

Titin Suhartini Kaaba ${ }^{l}$

Iin Apriliyani Pauba ${ }^{2}$

${ }^{1}$ Corresponding author, Tadris Bahasa Inggris, FITK. IAIN Sultan Amai Gorontalo, Gorontalo, Indonesia; titinkaaba27@gmail.com

${ }^{2}$ Tadris Bahasa Inggris, FITK. IAIN Sultan Amai Gorontalo, Gorontalo, Indonesia; iinpauba13@ gmail.com

\begin{abstract}
The objective of this research is to analyze the needs of students in reading text material in SMK Technology Muhammadiyah at Health Analisis Department. This research was conducted in class X majoring in Health Analisis in SMK Technology Muhammadiyah. The type of research method used was qualitative with a total number of participants of twenty people. The data was collected through questionnaires and open-ended interviews. The data was then analyzed using descriptive qualitative techniques that consist of 1) data preparation, 2) all data reading, 3) process of coding, 4) carefully description, 5) narrative approach, 6) data presentation. The results of this study indicate that there are three things needed to be achived by students of SMK Technology Muhammadiyah they are: 1) Necessity about reading material on the topics of health terms, medical devices. 2) Lacks in the form of material incompatibility taught with material needed by the students. 3) Wants covering material that students want to learn and that never been taught. The implication from this research is that students can achieve learning goals based on the material they need.
\end{abstract}

Keywords: Reading Text Material; Students' Need Analysis.

\section{Introduction}

English learning at vocational high schools has one very important problem in learning materials where in Indonesia apply the curriculum that contains the materials and distributed to all schools both public and vocational school. The government was aware of that problem by setting education regulation No. 29/1990 article 1 paragraph 3 states that vocational education is an education that priotizies the ability of development of students to have special skills (Syaddad, 2010). It means that English teaching at Vocational High School should consider the English required in the target situation of each study because vocational students are prepared to work right away after they graduated. So, the students are expected to be able to focus on the specific material, which has a correlation with their major. Therefore, the material in teaching english at vocational high school has an important role in its implementation. According to Hutchinson and Waters (1983, p. 61) in developing the materials, the target needs and learning needs, of the students must discovered by conducting 
the need analysis in order to meet the materials with the learners' needs and interests. It means teaching material become crucial issue because it will give significant impacts towards reaching teaching and learning target so that the learners get benefit of teaching learning process and prepare their future work.

Hence, teaching material in Vocational High School should relate to students' needs in their workplace such as electronic enginerring, management, economic and bussiness, public health and so on because inappropriate of teaching material will not help students to get the objectives of teaching learning. In other word, teaching material becomes one of the main problems faced in teaching-learning process at vocational high school today, especially in English subject. It is due to the materials in English subject contains four skills; they are listening, speaking, reading and writing. Those are important to master but for my students, reading is more needed. Particularly, in Analisis Kesehatan Program is clearly one of important language skill where students have to read English material of their subject and they are demorded to read more medical journals in term. The students often thought to be easier to obtain information from written text by reading.

Reading is known as an interactive process between the reader and the text also conditions are created to enable students to learn to read (Jhonson, 2008). Mariane and Elite (2000, p. 119) state in their book Discourse and Context in Language Teaching that in the process of reading, there are three participants: text, writer and reader. It is the process of understand a written text, simultaneous tasks, decode the message, interpret the message, and finally understand what the author's intention was. It's all what the reader shouls do. Therefore, reading is one of the linguistic skills that people should have in order to communicate in English fluently and it is important to understand information from the text and interpret its meaning. It is also most important for vocational school, because students will more easily understand if the themes and topics of their reading text are appropriate with their major. Concerning these, the English learning materials should be designed based on the students' need in order to support the english learning process. According to Jhonson reading material are allowed choose by the students. Besides, the learning materials should be contextualized with their study program. Based on interview in pre-observation with the student of first grade Analisis Kesehatan at SMK Teknologi Muhammadiyah about their material in reading text it was found that the reading text that they use is still inapproprate. It is also proven by teachers' English book to teach in vocaional high school still contains general english topic. Meanwhile, the pre-service students are expected to mastering their major through in english in reading text. The concepts above, make the researcher interested in 'analyzing students' needs on reading text material at vocational school". The purpose of this research is to analyze students' need on reading text material. Hopefully, this research could provide input to teachers in SMK Teknologi Muhammadiyah to better understand the material correlate with students' need that applied in curriculum 2013.

Need analysis in a language program is viewed simply as identification of the language forms that the students will need to use in the target language. As Mackay and Palmer (cited in Wello \& Dollah, 2008, p. 65) stated that "need analysis procedures may involve interview with students to determine perceptions of their major language difficulties, interviews with lectures and instructors, observations of students in class to observe how well they can carry their assignments, examinations of their lectures notes, essays, and so on to determine their difficulties, as well as tests of different kinds to determine students level of proficiency in 
reading, writing and note taking". In need analysis it is important to know about target needs (Hutchinson \& Waters, p. 56). Target needs are divided into three parts. There are necessities, lacks and wants.

Necessities Lacks Wants

The type of need determined Lacks talks about what Target needs are an objective by the demands of the target the learner knows sense, with the actual learners situations or what the already, so that can be learners has to know in decided which of the order to function effectively in the target situations. necessities the learners playing no active role. But the learners too, have a view as to what their needs are. lack.

Besides target needs there is also target situation analysis framework. It helps the researcher or teacher to gathering the need analysis. Target situation needs means what the learner is required to perform in the target situation. TSA depends on asking questions about the target situation and the attitudes of the participants toward that situation. It includes six main questions, which are further divided into several other questions. The main questions ask about the purposes for which the language is needed, how the language is used, the content areas, who is involved in the communication process, the context in which the language will be used, and the time when the language will be used. Hutchinson and Waters (p. 73) further line a target situation and learning analysis framework as follow.

\begin{tabular}{ll}
\hline Why is the language needed? & $\begin{array}{l}\text { For study? } \\
\text { For work? } \\
\text { For training? }\end{array}$ \\
\hline How will the language be used? & $\begin{array}{l}\text { Medium : speaking, writing, reading, or writing } \\
\text { Channel: telephone, face to face } \\
\text { Types of text discourse: academic texts, lectures }\end{array}$
\end{tabular}

\section{What will the content areas be? Subjects: medicine, biology, engineering Level: technician, secondary school}

Who will the learner use the Native speaker, non-native speaker language with?

Level of knowledge of receiver: expert, students

Relationship: colleague, teacher, customer 
Where will the language be used? Physical setting: office, hotel, library

Human context: alone,

meeting, demonstrations

Linguistic: abroad

When will the language be used? Concurrently with the ESP course

Frequently, seldom, in small amounts

\begin{tabular}{ll}
$\begin{array}{l}\text { Why are the learners taking the } \\
\text { course? }\end{array}$ & Compulsory or optional Apparent need or covert \\
\hline How do the learners learn? & $\begin{array}{l}\text { What is the learning background? } \\
\text { What is their concept of teaching and learning? }\end{array}$ \\
$\begin{array}{ll}\text { What resources are } \\
\text { available? }\end{array}$ & $\begin{array}{l}\text { Number and professional competence of teacher } \\
\text { Attitude of teachers to ESP }\end{array}$ \\
\hline Who are the learners? & $\begin{array}{l}\text { Age/sex/nationality } \\
\text { What do they already know about English? }\end{array}$ \\
$\begin{array}{ll}\text { Where will the ESP course take } \\
\text { place? }\end{array}$ & $\begin{array}{l}\text { Are the surroundings } \\
\text { pleasant, dull }\end{array}$ \\
When will the ESP & $\begin{array}{l}\text { Time of day } \\
\text { Every day/ once a week } \\
\text { course take place? }\end{array}$ \\
\end{tabular}

Material has an important role in learning process, especially in reading. Reading material itself consists of text. Text means a process of transferring message to the readers or listeners. According to Halliday and R. Hasan $(1985$, p. 6) that text is meant any connected stretch of language that is doing job in some contexts. In addition, text is used to convey English material and as one of the four skills targeted in learning. Therefore, in learning process text or reading text is delivered in various genres.

The term "genre" has been used for many years to refer to different styles of literary discourse. Genre is one of the most important concepts in language education. Genre also can be as a culturally specific text type which results from using language to accomplish something. Each genre is characterized by distinctive schematic structure, that is, by a distinctive beginning, middle, and end structure through which the social function of the genre is realized.

There are some kinds of genre that taught in $10^{\text {th }}$ grade at vocational high school, they are procedure text, narrative text, descriptive text and news.

\section{Method}

A qualitative descriptive as an approach method was applied in this research. According to Sugiyono (2014, p. 192), a qualitative descriptive research method is the research method used to examine the condition of the object that is natural, (as it opponent is an experiment) where the researcher is a key instrument, data collection techniques 
triangulation (combined), data analysis is inductive, and qualitative research results further emphasize signification of the generalization.

Based on the statement above, this research was used qualitative descriptive as suitable approach method, which analyze students' needs on reading text material and describes the finding. The writer used qualitative descriptive, because the result of this research is describing data.

\subsection{Respondents}

This research is conducted in SMK Teknologi Muhammadiyah. It is located at Jl. Abdul A. Wahab, Hunggaluwa village, Limboto district, Gorontalo regency. Subject of research is $10^{\text {th }}$ grades consists of 20 students of Analisis Kesehatan Program.

\subsection{Instruments}

Instrument in this research was questionnaire and unstructured-interview. Questionnaire was to analyse students ${ }^{\text {ee }}$ needs on reading text material of their major and unstructured interview to pressure the results of questionnaire.

\subsection{Procedures}

The researchers combined Jack Ricahrds and Basri Wello theory to make the instrument.

This research uses several data collection techniques, namely:

\subsubsection{Unstructured Interview}

The researcher was used unstructured interview to collect the data. Interview is known as an oral process to get information through asking-answering question. The unstructured interview is an interview without systematic interview, the researcher only use a highlight problem in interview (Sugiyono, 2016, p. 191).

\subsubsection{Questionare}

The researcher was used questionnaire to collect the data about students ${ }^{\text {ee }}$ needs on reading text material. As Creswell (cited in Sugiyono, 2016, p. 192) stated that questionnaires are form used in a survey design that participant in a study complete and return to the researcher. In this questionnaire the indicators were taken from Richard and Wello but some part is modified to get students of Analisis Kesehatan Program needs on reading text material. Questionnaire is consisting of a series questions (or other types of prompts) for the purpose of gathering information from respondents. The blue print of each instrument is presented below.

Blue-print of Need Analysis Questionnaire

\begin{tabular}{cll}
\hline No. & \multicolumn{1}{c}{ Indicators } & Total \\
\hline 1. & Reading types and the frequency of difficulty & 10 items \\
\hline 2. & Reading material & 5 items \\
\hline 3. & Topics of reading text material & 11 items \\
\hline 4. & Reading difficulties & 11 items \\
\hline
\end{tabular}




\subsection{Data Analysis}

In analyzing the data of students ${ }^{\text {ee }}$ needs on reading text material, the researcher used descriptive qualitative. The various information and data obtained in this research was analyzed by using the following formula:

$$
X^{=\frac{\sum \mathrm{X}}{\mathrm{n}} \times 100}
$$

Note:

$X \quad$ : The average of the survey response

$\sum \mathrm{x} \quad$ : The numbers of students choose each item

n : The total of the students as the participants

After that, researcher gained students respond into statistical recapitulation and the result is displayed into chart. It is help to analyze and discusses based on the indicators.

There was several steps researcher use in analyzing the data based on Creswell (2003, p.191-195) theory that would be explained below.

STEP 1: The researcher organized and prepared data or students response in questionnaire and interview to get students ${ }^{\text {ee }}$ needs on reading text material. After that researcher scanned the data and arrange the data.

STEP 2: The second steps, after organized and prepare the data, researcher red the data carefully and tried to analyze the studentse needs on reading text material to obtain the information and reflected on its overall meaning.

STEP 3: In this step, researcher begin the coding process to detailed analysis. Its mean researcher divine the data based on the indicators and the research question could be answered by this step.

STEP 4: The researcher was used the result of coding process to generate a description. Then, describe in detail the information that the researcher got in some steps of conducted the research such as questionnaire and interview.

STEP 5: In this step, the researcher used narrative approach to explain the data that found in this process of research.

STEP 6: In the final step, researcher interpreted the data and explain the final result of this research based on the entire steps. That explanation supported by theories in the previous chapter.

\section{Finding and Discussion}

\subsection{Finding}

Analyzing students' needs on reading text material at Vocational High School is important to determine what actually students ${ }^{\text {ee }}$ need in learning English. Therefore, the researcher collected the information or the data from students through questionnaires and unstructured interview. 
This research was done by conveyed the questionnaire sheet to all students and interviewing them. In the presence of interview, it was helped to dig more about what is actually students' necessity, lack and want in English learning based on their answer in questionnaire.

The following tables describe findings gained from students' responses toward questionnaire and also researcher added some statement from student about items that was offered by researcher. The results were presented per indicators as follows:

Indicator1. Reading types and the frequency of difficulties

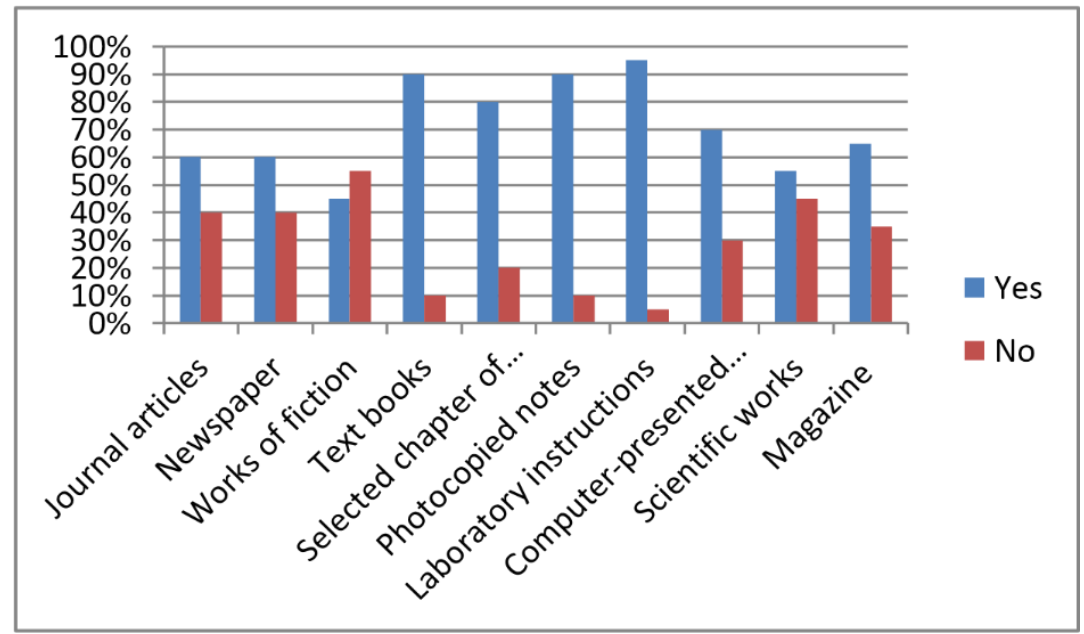

\section{Chart 1. Reading types}

Based on the chart above, the highest percentage of reading types that was chosen by students are laboratory instructions and textbook. As students of Analisis Kesehatan, laboratory instructions can help them to learn such laboratory instructions details in English. Therefore this offered was the highest among other offers with 95\% (19 students) choose „Yese while 5\% (1 student) chose „No" ${ }^{\text {ee }}$ Text book was the second highest choice with $90 \%$ (18 students) „Yese voted and $10 \%$ (2 students) chose „No ${ }^{\text {ee }}$. It was because the most common reading type in SMK Teknology Muhammadiyah was text book and they became used to it.

Frequency of difficulties 


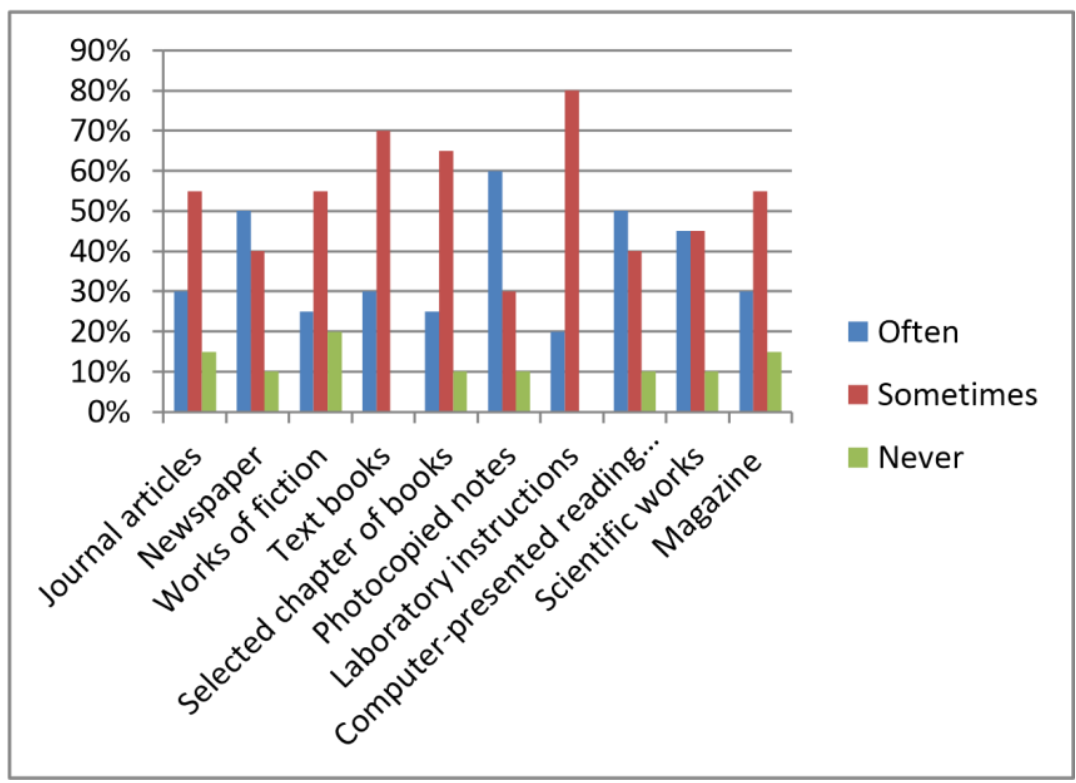

This chart explains about frequency of difficulties in reading types that students might get. The sixth reading type was photocopied notes. In the first chart photocopied notes was the second highest percentage that students choose. So, it possible that $60 \%$ (12 students) often find this reading type difficult, while $30 \%$ (6 students) chose sometimes. And the rest $10 \%$ (2 students) chose "never".

The eight reading type was computer-presented reading material. There were $50 \%$ (10 students) often finding the difficultness of this reading type. Besides $40 \%$ (8 students) chose "sometime" and only 10\% (2 students) chose "never".

\section{Indicator 2. Reading material}

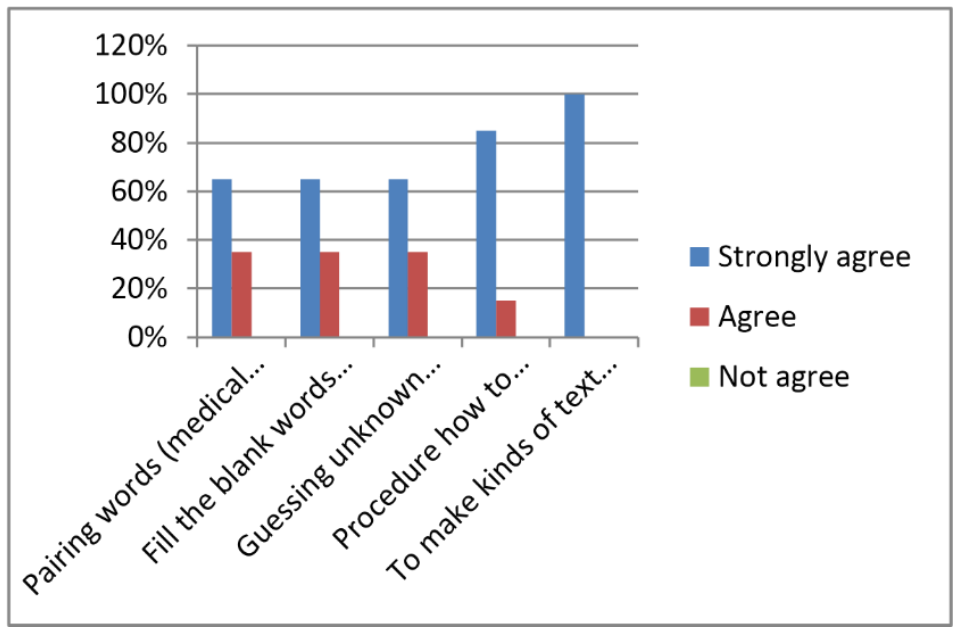

The second indicator was reading material. The chart presented the percentage of how many students want those reading materials. The chart showed us that the fourth reading 
material "procedure how to operate medical tools" was much awaited by the students. From the results of percentage was quite high $85 \%$ (17 students) chose "strongly agree" and only the rest $15 \%$ (3 students) chose "agree" also based on interview mostly student want this reading material and Rilan Glasi (students of Analisis Kesehatan program) said this kind of reading material is should be applied.

\section{Indicator 3. Topics of reading text material}

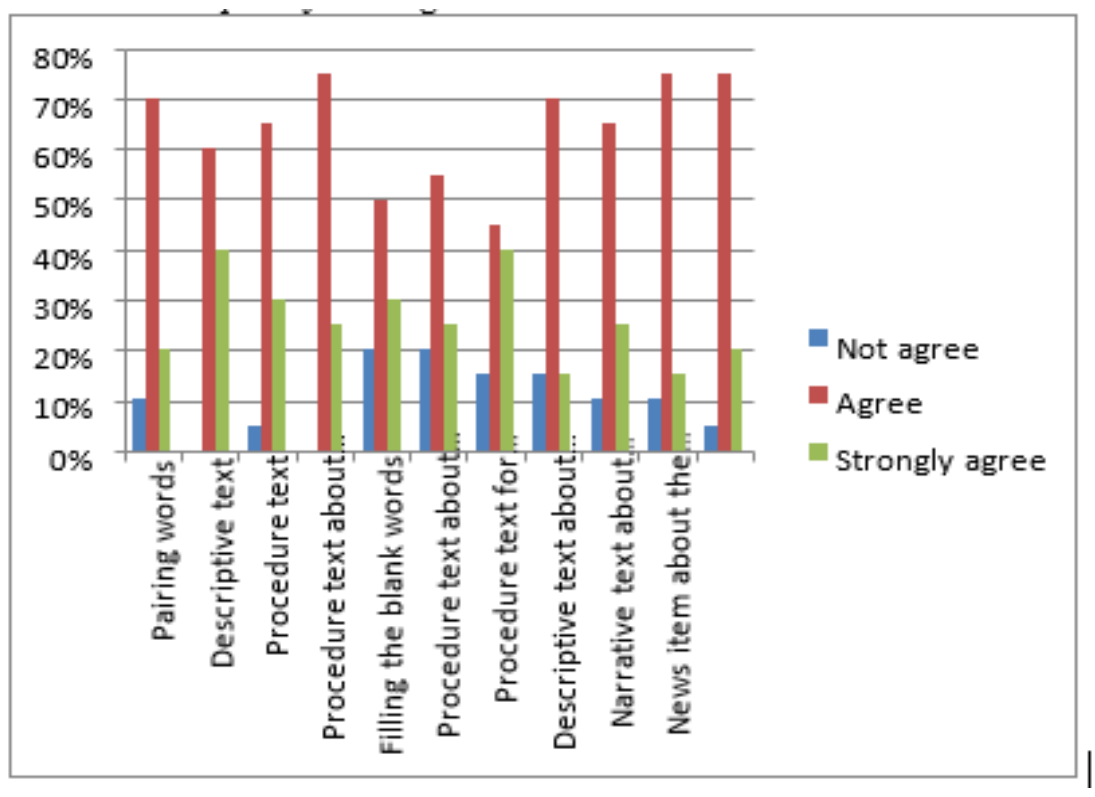

The chart showed that the procedure text about how medical devices work got the highest percentage. Among 75\% (15 students) chose agree and 25\% (5 students) chose strongly agree. The researcher offered this reading topic because as Analisis Kesehatan students might be wondered how medical devices work and how they can know that by English language.

Indicator 4. Reading difficulties

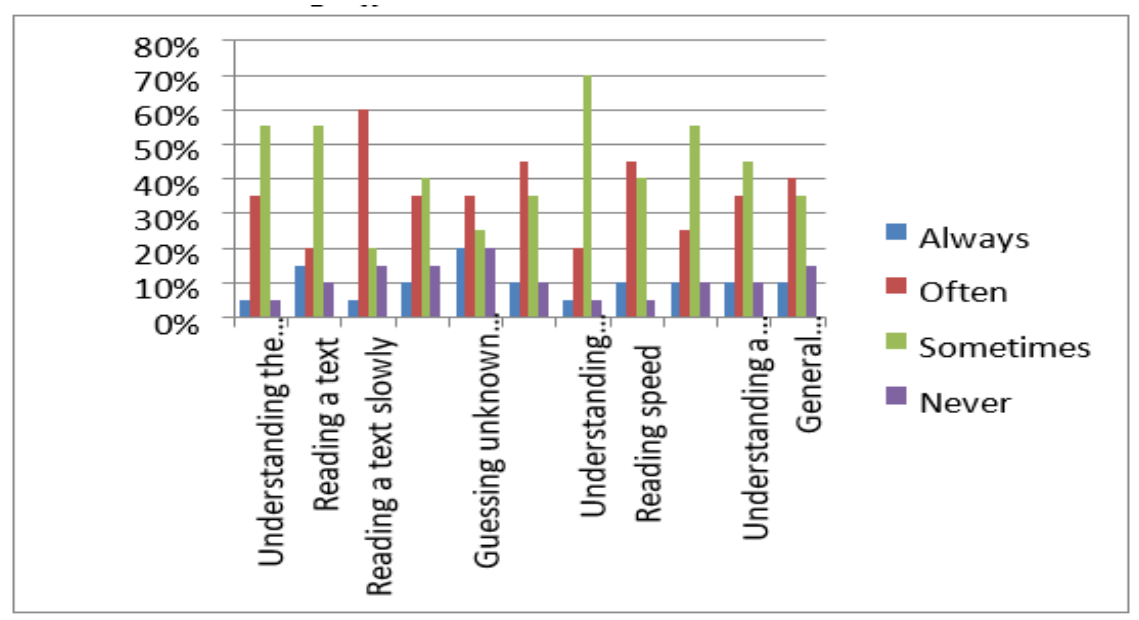


The chart above was explained about reading difficulties that was chosen by students gained from questionnaire. In this chart showed how many percentages students' difficulties on reading in each item. The first item was understands the main points of the text. This item showed that 5\% (1 student) chose always, 35\% (7 students) chose often, 55\% (11 students) chose sometimes and 5\% (1 student) chose never.

\subsection{Discussion}

This research aims to analyze students' needs on reading text material. The researcher presented the indicator and its item one by one to analyzing students ${ }^{\text {ee }}$ need and explained it by target needs model.

Laboratory instructions was the highest percentage among those three reading types became student ${ }^{\text {ee }}$ favorite. As a student of Analisis Kesehatan they all expected laboratory instructions can be used as one of the reading type in school.

\section{Necessity}

Laboratory Instructions helped them to know more about everything in laboratory through English. Also, Fikriyanto Kai said that all tools in laboratory were named with English and they hoped they also can read laboratory instructions in English.

\section{Want}

As the medical students (Analisis Kesehatan) they were want laboratory instructions can be applied as their reading type and the instructions is already in English language. Muhammad alyafar Dai stated that all the students of Analisis Kesehatan really want to read laboratory instructions in English because it was a best activity in learning process.

\section{$\underline{\text { Lack }}$}

The researcher found that laboratory instructions was already applied but unfortunately the fact is laboratory instructions still in Indonesian language and that was obviously not help students to reach the objectivities of English learning.

Procedure how to operate medical tools. This reading material was much awaited by the students. From the results of percentage was quite high $85 \%$ (17 students) chose "strongly agree" and only the rest 15\% (3 students) chose "agree" also based on interview mostly student want this reading material and this kind of reading material is should be applied.

\section{Necessity}

First of all, Analisis Kesehatan was a program that aims to make students work in medical areas. Therefore, it was crucial apply the material about procedure how to operate medical tools.

Want

From the percentage result it can be seen almost all students agree if this reading material is applied in English subject. The students know what are they want in learning so it is why seventeen students chose "agree" for this item. Also, based on Patel and Jain stated Reading is an important activity in life with which one can update his/ her knowledge. 
$\underline{\text { Lack }}$

As the statement of a student above, it can be seen the lack of procedure how to operate medical device is came from school because the school still not conveyed them the appropriate material.

The third indicator was topics of reading text material. In this part the researcher only presented the highest percentage from the whole topic of reading material above as follow as;

\section{Necessity}

The topic of reading material with the highest "Agree" percentage (75\%) was how medical devices work, the right actions for patients and descriptive text about laboratory technology experts. It can be seen that those topics of reading can be interpreted as the necessity of student.

\section{$\underline{\text { Want }}$}

The researcher concludes that all topics of reading that offered by researcher can be applied in a text as their needs on English subject. Most of students wanted the items can be applied or use in English learning. It was because all the items the researcher offered is about their major. So, they wanted those items about reading text material can helped them to understand about their major through English.

\section{$\underline{\text { Lack }}$}

Based on the interview and percentage of questionnaire it can be seen there are lack both teacher and students. Which is teacher did not give an appropriate material nor does not give those reading topics. So, the students did not reach their target needs yet.

The last indicator about reading difficulties that was chosen by students gained from questionnaire. In this chart showed how many percentages students ${ }^{\text {ee }}$ difficulties on reading in each item. There were eleventh reading difficulties researcher offered.

\section{Necessity}

Reading difficulties was aim to in fixing the problem that student got in English learning also it can be the guidance for teacher to teach English especially in reading material and its topics.

\section{$\underline{\text { Want }}$}

From the percentage result it can be seen that the percentages difficulties faced by students still high. Therefore, mostly students want their problem in reading can be solved with the appropriate material and the guidance from teacher.

\section{$\underline{\text { Lack }}$}

From the student's statement of students and the result of percentage it was showed almost all students have difficulty in reading. It indicates that there is a mistake from the teacher in delivering the material or from the students himself who is not focused in receiving the material 


\section{Conclusion}

It was found that reading text material at SMK Teknology Muhammadiyah as Vocational High School is still inappropriate especially in Analisis Kesehatan Program. It was proven by teachers' textbook that used in English teaching and students ${ }^{\text {ee }}$ interview. Researcher analyzed students ${ }^{\text {ee }}$ needs on reading text material to help them achieve the objectives of learning process. The data was gained from questionnaire and unstructured interview with students. The result of questionnaire was presented on statistical computer then researcher made the target needs and added students' interview to analyze their needs on reading text material based on the indicators were offered. The target needs found in this research was 1) Necessity, from the findings and discussion it was definitely showed that as medical laboratory technologist they are expected to diagnose, treat and prevent disease through clinic laboratory tests. They played an important role in medical science and those as their necessity in future work. 2) Lacks, after explained the necessity, researcher found the lack of learning process at SMK Teknology Muhammadiyah especially on reading text material it was showed that what students already know and studentsee necessity are not match. 3) The last target needs are Wants, in fact the necessity and students ${ }^{\text {ee }}$ wants is something in common. It can be seen on the percentages and students' interview. 


\section{References}

Celce-Murcia, Mariane and Elite Olshtain. (2000). Discourse and Context in Language Teaching. United Kingdom: Cambridge University Press.

Creswell, John W. (2003). Research Design: Qualitative, Quantitative, and Mixed Method Approaches Second Edition. London: Sage publications, Inc.

Halliday, M.A.K and R. Hasan. (1985) Language, Context, and Text: Aspect of Language in a Social-Semiotic Perspective. Oxford University Press.

Harmer, Jeremy. (2007). The Practice Of English Language Teaching. Pearson Education Limited

Hutchinson, Tom and Alan Waters. (1983). English For Specific Purpose. Cambridge University Press.

P. Jhonson, Andrew. (2008). Teaching reading and writing. Rowman \& Littlefield Education.

Richards, Jack C. (2001). Curriculum development in Language Teaching. Cambridge University Press.

Syaddad, Farhan . )“Undang-Undang Sistem Pendidikan Nasional”, sabtu 16 april 2011. (online, diakses dari (https://www.google.com/amp/s/farhansyaddad.wordpress.com/2010/07/07/undangundangsistem-pendidikan-nasional/amp/, accesses on July 04, 2019)

Sugiyono. (2014). Memahami Penelitian Kualitatif. Bandung: Alfabeta.

Sugiyono. (2016). Metode Penelitian Kuantitatif, Kualitatif Dan Kombinasi. Bandung: Alfabeta.

Wello, M. Basri \& Dollah, syarifudin. (2008). Fundamental aspects of English for specific purposes. UNM Publisher. 